\title{
Ukraine: The New Reforms and Internationalization
}

\section{Sonja Knutson and Valentyna Kushnarenko}

Sonja Knutson is director, International Centre Memorial University of Newfoundland, Canada. E-mail: sknutson@mun.ca. Valentyna Kushnarenko is research associate, Ontario Institute for Studies in Education, University of Toronto, Canada. E-mail: val.kushnarenko@ utoronto.ca.

$\mathrm{T}$ he internationalization of higher education in Ukraine continues to be vulnerable to the tensions of the region's geopolitics. Since our previous analysis of the Ukrainian context of internationalization (IHE \#75, Spring 20I4), serious hostilities have arisen with Russia over eastern Ukraine. Despite the distraction of war, on July 3I, 2014 Ukrainian President Petro Poroshenko signed the Law on Higher Education, significant because it is the first such law developed through consultation with the Ukrainian public. The process of consultation with educators, experts, community members, journalists, students, parents, and nongovernmental organizations was not without controversy, but the result demonstrates the perseverance and vision of the stakeholders. The new law sets the stage for Ukrainian higher education to act with greater autonomy, accountability, and transparency, enabling more nimble responses to international opportunities. A number of the new law articles are discussed.

\section{Greater Autonomy}

Under the new law, universities are able to act with greater autonomy to maximize their own interests, expertise, and potential. The reforms promote decentralized decision making and a forum for faculty, students, and other stakeholders to voice opinions on university management and curriculum development. University staff traditionally defer "upstairs" for direction, thereby stalling important decisions and avoiding responsibility. The reforms will create significant shifts in the usual business of the university, requiring a new approach to leadership by charging administrators with staff engagement, decentralized decision making, and responsibility for reputation. If successfully implemented, reforms have the potential to usher in a new age of creativity and innovation, both critical components of globalization, in the Ukrainian higher education system.

\section{Quality Assurance}

The implementation of quality-assurance processes is a significant step forward in improving the transparency of university accreditation in Ukraine. The new processes are supported by the creation of the "National Agency for Higher Education Quality Assurance in Higher Education." The former highly bureaucratized Ministry of Education Quality Verification Unit was criticized for being ineffective and slow. According to Minister of Education, Serhiy Kvit, tackling quality assurance will allow Ukrainian universities to engage internationally and aim for higher international university ratings. Article \#I9 of the new law specifies the composition of the new independent body: university and professional representatives, specialists from the Academy of Sciences, employers and elected students representatives. The public monitoring of the law's implementation should improve overall credibility, signifying the beginning of the end of corruption schemes in the Ukrainian academic sector. An independent agency has been formed to administer tests for undergraduate admissions, while article \#4I encourages student government to be active in cases of corruption, expulsion, appointments of senior administration, and unfair administrative decisions at university family housing and dormitories. The transparency of university budgets is legislated in the law's article \#80, with reports on university spending available for public scrutiny. Such measures should make it difficult to sustain under-the-radar accounting practices, opening the door to corruption reduction by making leaders accountable to public stakeholders.

\section{Global rankings, though increasingly under fire for overly limiting the defini- tion of higher education excellence, re- main an important component of the public face of a university.}

\section{Bologna Compliance}

The creation of favorable conditions for global mobility of people and knowledge is an important component of internationalization. Ukrainian students should be able to study abroad without suffering academically, and international students at Ukrainian universities will only benefit if academic credit transfer is standardized with clearly defined processes. Under the Bologna Declaration in 2005, then Minister of Education and Science Stanislav Nikolyaenko committed Ukraine to serious legislative changes in order to transition the higher education system to the three cycles of bachelor, master's and $\mathrm{PhD}$ degrees, to introduce the European Credit Transfer System and to reduce classroom 
hour loads for students and faculty. Yet today, Bologna terminology is rarely used in official documents or on university campuses. The law's article \# $\mathrm{I}$ of the new legislation defines an academic credit and the number of credits in a full-time academic year, creating norms that will facilitate international academic collaboration and enhance student mobility. Furthermore, the introduction of a PhD degree at Ukrainian universities significantly benefits global mobility of Ukrainian scholars, whose home status of "candidates of sciences" is not well-understood abroad. Global awareness of the "candidates of sciences" degree has been further muddied by a lack of clarity around the role of the Ukrainian Academy of Science, which had the exclusive right to grant these degrees. The process now will more closely mirror norms in other countries, including required courses, research, and dissertation defense in the presence of a university committee comprised of research field specialists.

\section{RESEARCH INTENSITY}

Global rankings, though increasingly under fire for overly limiting the definition of higher education excellence, remain an important component of the public face of a university. Those universities with good rankings and a strong reputation attract the best talent, whether in faculty, staff, or students. Thus, the quality of research and number of publications in reputable peer reviewed journals is increasingly important to the viability of an institution. Under the new law, Ukrainian universities are expected to intensify research capacity and production. Faculty, traditionally overloaded with more than 900-950 hours/year of classroom teaching, will see a decrease in their load to 600 hours/year. This is a significant change to free up academic staff for other scholarly pursuits, which can support the overall institutional goals, in particular for research and travel related to international research collaborations. These transformations pose a major shift to the status quo, and those that are slow to respond may find themselves quickly on the periphery and unable to access resources that are increasingly tied to international engagement.

\section{IMPACT OF INTERNATIONALIZATION}

Universities around the world struggle to respond to the demands and opportunities of globalization, thus the need for skilled change management is by no means a uniquely
Ukrainian problem. Universities tend toward hierarchical and bureaucratic self-organization and are notoriously resistant to change. The Ukrainian higher education system is perhaps starting at an earlier place than other countries where universities are freer to choose program content, make financial decisions, create degree granting and credit transfer policies, and hire faculty via open and transparent competition. In Ukraine, such innovations could be jeopardized if opposition causes delays to change, creating uncertainty, and lowering morale. On the positive side, there is much work already done on best practice for change management in higher education that could support Ukrainian universities to move through stages of change more quickly. The more accessible Ukrainian higher education can make itself to the world through internationalization, the more easily change will take root.

\section{CONCLUSION}

Successful implementation of these new reforms will prepare universities in Ukraine with tools to benefit from international opportunities. The effect of ongoing hostilities in the east of the country is challenging and may have unpredictable effects on the implementation and timing of specific reforms. A critical factor is the development of robust policies and processes, to manage the reforms in a fair and transparent manner to avoid backlash and further destabilization. Capacity building by those who have developed expertise in more decentralized systems-such as Ukrainian alumni who studied abroad, or other international experts will need to be engaged, to participate in the development of new processes-support new roles in educational administration and prepare a new cadre of education leaders with a progressive approach to education. Campus communities will need to be resilient, energetic, and optimistic to maintain the levels of motivation to impel change forward. Perhaps the motivation for Ukrainian higher education's commitment to educational reform is best summed up by Mykhaylo Zhurovskyi, Rector of the Kyiv National Technical University, and one of the authors of the new law who stated publicly that Ukraine has no other alternative but to begin to change its mentality and work hard to create a new country.

\section{NEW PUBLICATIONS}

Cantwell, Brendan, and Ilkka Kauppinen, eds. Academic Capitalism in the Age of Globalization. Baltimore: Johns Hopkins University Press, 2014. 277 pp. \$34.95 (pb).
ISBN 978-1-4214-1538-3. Web site: www. press.jhu.edu.

The idea of academic capitalism, which in general links neoliberal ideas with the growing marketization and privatization of higher education, was developed over the past two decades by Sheila Slaughter and her colleagues. This volume is based on the concepts of academic capitalism and provides case studies that used these concepts to analyze such themes as the historical development of universities, patents in the knowl- 